\title{
Estimation of some biochemical parameters and trace elements in sheep infested with Taenia hydatigena cysts in Sulaymaniyah province/Iraq
}

\author{
A.A. Mohammed ${ }^{1 *}$ and M.A. Kadir ${ }^{2}$ \\ ${ }^{1}$ Department of Microbiology, College of Veterinary Medicine, Sulaimani University, \\ ${ }^{2}$ Department of Microbiology, College of Medicine, Kirkuk University, Iraq \\ Email: ${ }^{1}$ aram.mohammed@univsul.edu.iq, aram7a@yahoo.com, ${ }^{2}$ mohammdsalam@yahoo.com
}

(Received March 11, 2019; Accepted April 10, 2019)

\begin{abstract}
This study was carried out in Sulaymaniyah province, Iraq to estimate the concentration of some biochemical parameters and trace elements in the serum of sheep infected with the metacestodes of Taenia hydatigena. The present study included the measurement of some biochemical parameters as total protein, albumin and globulin and evaluation of trace elements as zinc, copper and iron using automatic analyzer and spectrophotometer respectively. For this purpose, up to 40 serum samples from sheep infected with $T$. hydatigena cysts and 10 serum samples from non-infected group had been used. The findings of the current study showed significant elevated levels in both total protein and globulin compared to non-infected group, where the total protein and globulin levels were $8.04 \pm 0.275 \mathrm{~g} / \mathrm{dl}$ and $5.90 \pm 0.321 \mathrm{~g} / \mathrm{dl}$ respectively, compared to the non-infected group $6.686 \pm 0.409 \mathrm{~g} / \mathrm{dl}$ and $4.124 \pm 0.479 \mathrm{~g} / \mathrm{dl}$ respectively. While, the mean serum albumin in infected sheep was significantly decreased $2.14 \pm 0.224 \mathrm{~g} / \mathrm{dl}$ compared to non-infected one $2.562 \pm 0.152 \mathrm{~g} / \mathrm{dl}$. About the results of trace elements, the serum $\mathrm{Cu}$ was significantly increased in infected group $1.42 \pm 0.466 \mathrm{mg} / \mathrm{L}$ compared to non-infected one $0.90 \pm 0.171 \mathrm{mg} / \mathrm{L}$, while the mean serum $\mathrm{Zn}$ concentration was significantly decreased in infected group $0.37 \pm 0.230 \mathrm{mg} / \mathrm{L}$ compared to non-infected group $0.70 \pm 0.108 \mathrm{mg} / \mathrm{L}$. Although, the mean serum Fe of infected sheep $1.42 \pm 0.388 \mathrm{mg} / \mathrm{L}$ was slightly lower than noninfected one $1.26 \pm 0.490 \mathrm{mg} / \mathrm{L}$, statistically there was no significant difference between them. It was concluded that $T$. hydatigena cysts had significant effects on serum total protein, globulin, $\mathrm{Zn}$ and $\mathrm{Cu}$.
\end{abstract}

Keywords: Cysticercus tenuicollis, Serum, Spectrophotometer Available online at http://www.vetmedmosul.com, (C) 2020, College of Veterinary Medicine, University of Mosul.

This is an open access article under the CC BY 4.0 license (http://creativecommons.org/licenses/by/4.0/).

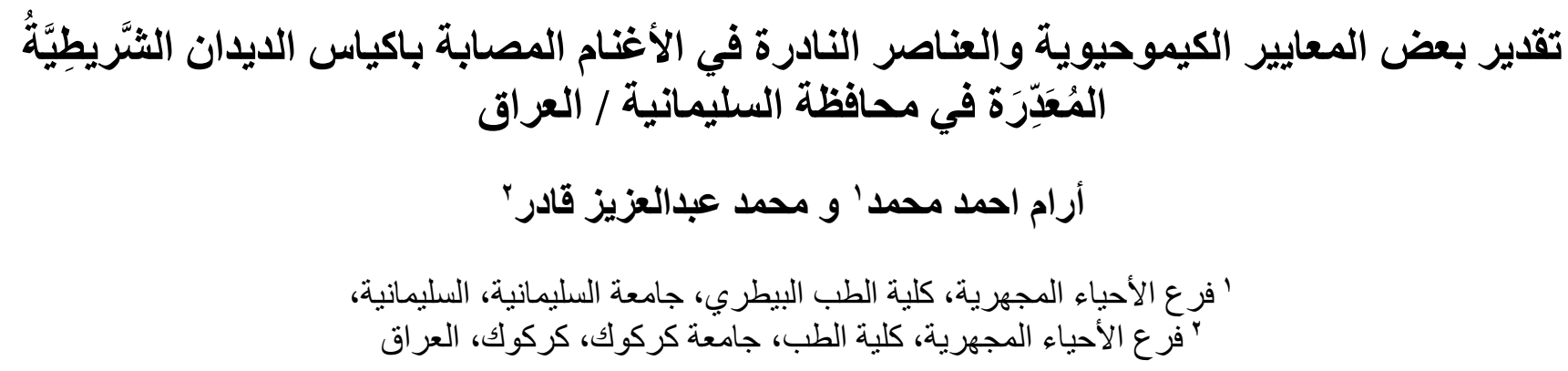

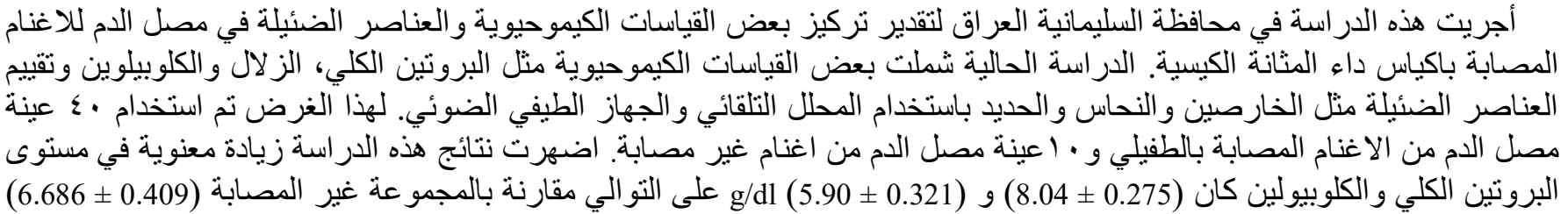




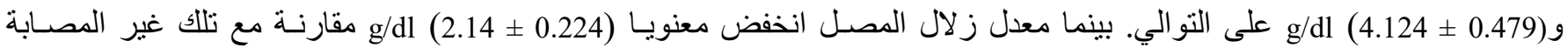

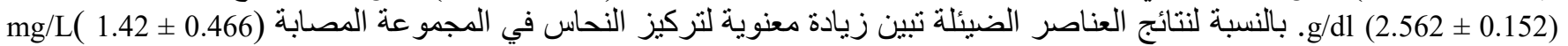

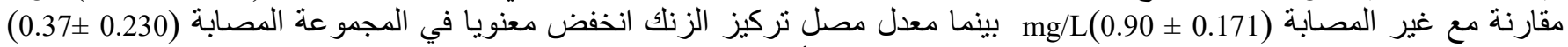

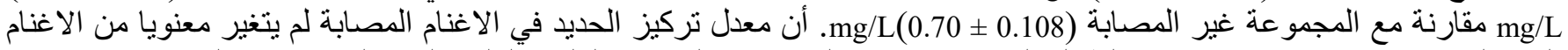

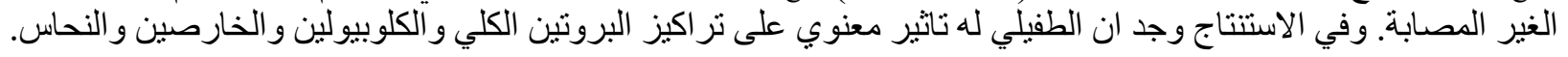

\section{Introduction}

Taenia hydatigena is a universal and boundless parasite of canids that can taint an extensive variety of warmblooded animals with its larval stage which is generally alluded to as $C$. tenuicollis (1). Cysticerci are typically found on the omentum, mesentery, peritoneum and less regularly, on the pleura and pericardium. The migrating larvae can be discovered for the most part in the liver parenchyma inside 7-10 days and may cause hepatitis cysticercosa in youthful animals (2). Most diseases are perpetual and asymptomatic and are not generally distinguished until slaughter (3). In overwhelming contaminations, the migrating larvae could create serious annihilation of the liver parenchyma with eosinophilic invasion and extreme irritation that could be lethal (4). Notwithstanding constituting an animal wellness issue, the parasitosis is a wellspring of financial misfortune for the meat business $(1,5)$. There are several of studies demonstrating the relationship of trace elements with parasitic diseases $(6,7)$. Some infectious diseases or chronic inflammation leads alteration in the level of trace elements but the reason is unknown yet and it needs more study $(8,9)$. There are two sorts of trace element abnormalities and it's generally known to be linked to dietary deficiency (10) or the imbalance due to different diseases (11). In all cases, serum elemental analysis is an experimental choice to evaluate the trace element status (12). In recent years, it is becoming increasingly clear that greater priority should be given to $C$. tenuicollis because of its economic impact due to condemnation of offal's containing these larvae, particularly in resource poor countries $(13,14)$. Loss in quantity or quality of meat or offal will have financial implications, with reduced payment for carcass contamination or diseases or infected tissues. Diagnosis of ovine cysticercosis in animals depends on the finding the gross cysts during meat examination or necropsy technique, while there are many valuable tests can be beneficial to diagnose the disease in livestock such as Enzyme Linked Immuno-Sorbent Assay (ELISA), hematological and biochemical tests (15). To the best of our knowledge, no previous study was conducted on $T$. hydatigena cysts in our region especially Sulaymaniya province, so it is decided to carry on the study to evaluate some biochemical and trace elements parameters in sheep infected with $T$. hydatigena cysts.

\section{Materials and methods}

\section{Animal selection, ante and post mortem inspection}

The study was carried out at Modern Sulaymaniyah Slaughterhouse in Sulaymaniyah province from $1^{\text {st }}$ of April to $30^{\text {th }}$ June 2017. Before the slaughtering animals were recorded for their breed, sex and age. The study was done on native breed of sheep. All the animals were originated from same farm, and only adult males were used. The study was done on two groups of sheep, infected animal and noninfected animals (control). Forty sheep carcasses infested only with the cyst of $C$. tenuicollis were selected randomly and the following organs were checked carefully to other parasitic diseases including lungs, gastrointestinal tract, liver, heart. The control group composed of ten of healthy animals that are free from any diseases (16).

\section{Blood sample collection and smear preparation}

Blood samples were collected from animals before slaughtering and biochemical and trace elements parameters were done only for those animals that had cysts after post mortem examination. About $10 \mathrm{ml}$ of blood sample was taken from the jugular vein of each sheep using sterile syringe with needle volume 22 gauges. Two $\mathrm{ml}$ of blood sample was directly put in anticoagulant tube, for blood smear technique and the rest of blood was put in plain tube without anticoagulant, and then the serum was separated from blood by centrifugation at $3000 \mathrm{rpm}$ for 20 minutes and stored at $-20{ }^{\circ} \mathrm{C}$ till it was used for trace elements and protein profile evaluation. The Giemsa stained blood smears were prepared and examined according to the procedure described by Zajac and Conboy (17) for detection of any blood parasites.

\section{Fecal sample collection and examination}

The fecal specimens were collected directly from rectum of sheep, then floatation and sedimentation techniques were done for each specimen according to the methods described by Zajac and Conboy (17) for detection of any gastro intestinal parasites.

\section{Serum total protein, albumin and globulin estimation}

An automatic analyzer was used to measure the serum total protein and albumin of both infected and non-infected groups of sheep (Cobas c311; Hitachi, Japan) at the laboratory of Baxshin Private Hospital/Sulaymaniyah city. 
The concentration of serum globulin was determined mathematically by subtracting the value of albumin from total protein concentration (18).

\section{Serum zinc, copper and iron concentration estimation}

To measure the level of $\mathrm{Zn}, \mathrm{Fe}$, and $\mathrm{Cu}$ elements in serum, Inductive Coupled Plasma Optical Emission (ICPOES) Spectrophotometer (Perkin Elmer DV2100, USA) was used at the quality control laboratory of Kurdistan Institution for Strategic Studies and Scientific Research / Sulaymaniyah city. In the present study, $213.857 \mathrm{~nm}$, $324.752 \mathrm{~nm}$, and $259.939 \mathrm{~nm}$ wavelengths were utilized to asses $\mathrm{Zn}, \mathrm{Cu}$ and $\mathrm{Fe}$ elements, respectively (Table 1) and the emission graphs of measured elements are illustrated in (Fig. 1).The Blank and standards solutions were calibrated. The serum samples were diluted with deionized water after blood centrifugation in a clean pretreated test tube by automatic pipette before analysis (19).

Table 1: Standards used for zinc, copper and iron $(\mathrm{ppm}=$ $\mu \mathrm{g} / \mathrm{ml})$

\begin{tabular}{lc}
\hline Standard name & ppm \\
\hline Std 1 & 1 \\
Std 2 & 3 \\
Std 3 & 5 \\
\hline
\end{tabular}

\section{Optimization of the serum samples}

In order to optimization of serum samples, a preliminary study was done on five infected and three non-infected groups of sheep sera to find the best dilution to perform the study. In this study deionized water was used to dilute sheep sera at ratios of 1:50, 1:100 and 1:200, for determining of $\mathrm{Zn}, \mathrm{Cu}$ and $\mathrm{Fe}$, respectively. The 1:50 dilution was chosen because there was no statistically difference between 1:50 and 1:100 dilutions.

\section{Statistical analysis}

Both SPSS version 24 and MS Excel (2010) software were used for statistical analysis. The results of trace elements and protein profiles are stated as mean \pm standard deviation (SD). Student's t-test was used to find statistical differences between study groups and $\mathrm{P}<0.05$ was regarded as significant value.

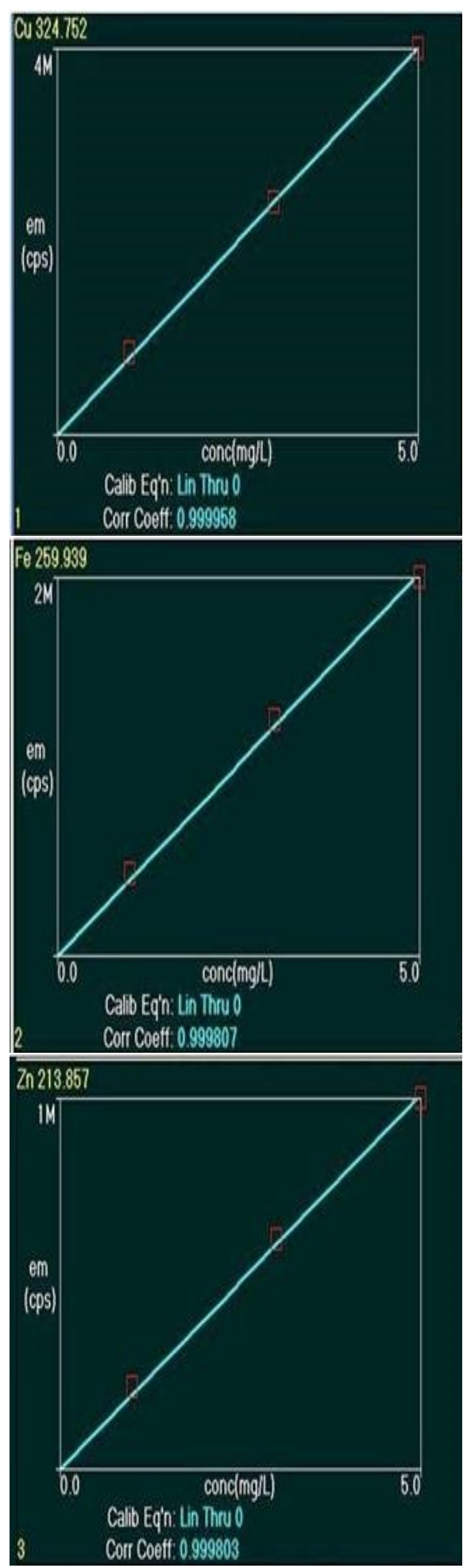

Figure 1: The emission graphs of $\mathrm{Cu}(1), \mathrm{Fe}(2)$, and $\mathrm{Zn}(3)$ for all standards as a function of concentration. 


\section{Results}

\section{Biochemical and trace elements parameters}

All changes in biochemical and trace element parameters recorded in this study represent the effect of $C$. tenuicollis only and not from other parasitic infection. For this purpose, blood smear and fecal examination were used to detect infected animals and separate them from noninfected group. In blood smears examination, no blood parasites were seen in both infected and non-infected groups with $C$. tenuicollis and also in fecal examination, no gastrointestinal parasites were observed in both groups.

\section{Protein profiles estimation}

C. tenuicollis had a clear effect on some serum protein in infected sheep. The serum total protein value in $C$. tenuicollis infected group was significantly $(\mathrm{P}<0.05)$ higher than non-infected group, as shown in (Table 2). There was significant difference $(\mathrm{P}<0.05)$ in serum albumin value between infected and non-infected groups.
The results indicated that $C$. tenuicollis had significant effect $(\mathrm{P}<0.05)$ on serum globulin value.

\section{Trace elements estimation}

The results of preliminary study on serum $\mathrm{Cu}, \mathrm{Fe}$ and $\mathrm{Zn}$ concentration measurement were shown in (Table 3). It seems from the results of this study that the $T$. hydatigena cysts had significant effect $(\mathrm{P}<0.05)$ on the $\mathrm{Cu}$ and $\mathrm{Zn}$ at $1: 50$ and 1:100 dilutions respectively, but no significant effect $(\mathrm{P}>0.05)$ on Fe concentration. On the other hand, there was no significant difference $(\mathrm{P}>0.05)$ in the average value of these trace elements between infected groups (Table 4). It appears that the serum $\mathrm{Cu}$ value was significantly increased $(\mathrm{P}<0.05)$ in infected group in comparison with non-infected group. While, serum $\mathrm{Zn}$ value was significantly decreased $(P<0.05)$. It was shown that serum $\mathrm{Fe}$ value in infected group was greater than noninfected control group but statistically no significant difference $(\mathrm{P}>0.05)$ between them, as illustrated in (Table 5).

Table 2: Serum protein profiles (Mean $\pm \mathrm{SD}$ ) in sheep infected with $C$. tenuicollis compared to non-infected sheep

\begin{tabular}{lccc}
\hline Protein profiles & Infected group $(\mathrm{n}=40)$ & Non-infected group $(\mathrm{n}=10)$ & P-value of T-test \\
\hline S. Total protein $\mathrm{g} / \mathrm{dl}$ & $8.04 \pm 0.275$ & $6.686 \pm 0.409$ & $* 0.000473$ \\
S. Albumin $\mathrm{g} / \mathrm{dl}$ & $2.14 \pm 0.224$ & $2.562 \pm 0.152$ & $* 0.000372$ \\
S. Globulin $\mathrm{g} / \mathrm{dl}$ & $5.90 \pm 0.321$ & $4.124 \pm 0.479$ & $* 0.000281$ \\
\hline
\end{tabular}

Table 3: Preliminary study on serum trace elements level (Mean $\pm \mathrm{SD}$ ) in sheep infected with C. tenuicollis compared to noninfected sheep

\begin{tabular}{llccc}
\hline Dilution & Serum trace elements & Infected group $(\mathrm{n}=5)$ & Non-infected group $(\mathrm{n}=3)$ & P-value of T-test \\
\hline \multirow{3}{*}{$(1: 50)$} & Copper $(\mathrm{Cu}) \mathrm{mg} / \mathrm{L}$ & $1.570 \pm 0.447$ & $0.970 \pm 0.026$ & $* 0.019775$ \\
& Iron $(\mathrm{Fe}) \mathrm{mg} / \mathrm{L}$ & $1.340 \pm 0.270$ & $1.230 \pm 0.233$ & 0.284971 \\
& Zinc $(\mathrm{Zn}) \mathrm{mg} / \mathrm{L}$ & $0.211 \pm 0.050$ & $0.630 \pm 0.085$ & $* 0.002620$ \\
\hline \multirow{3}{*}{$(1: 100)$} & Copper $(\mathrm{Cu}) \mathrm{mg} / \mathrm{L}$ & $1.542 \pm 0.408$ & $0.967 \pm 0.029$ & $* 0.016970$ \\
& Iron $(\mathrm{Fe}) \mathrm{mg} / \mathrm{L}$ & $1.372 \pm 0.275$ & $1.220 \pm 0.226$ & 0.217202 \\
& Zinc $(\mathrm{Zn}) \mathrm{mg} / \mathrm{L}$ & $0.203 \pm 0.043$ & $0.617 \pm 0.085$ & $* 0.003375$ \\
\hline
\end{tabular}

Table 4: Preliminary study on serum trace elements level (Mean $\pm \mathrm{SD})$ in sheep infected with C. tenuicollis

\begin{tabular}{lccc}
\hline Serum & Infected group $(\mathrm{n}=5)$ & Infected group $(\mathrm{n}=5)$ & $\begin{array}{c}\text { P-value of } \\
\text { trace elements }\end{array}$ \\
$1: 50$ dilution & $1: 100$ dilution & T-test \\
\hline Copper $(\mathrm{Cu}) \mathrm{mg} / \mathrm{L}$ & $1.570 \pm 0.447$ & $1.542 \pm 0.408$ & 0.460036 \\
Iron $(\mathrm{Fe}) \mathrm{mg} / \mathrm{L}$ & $1.340 \pm 0.270$ & $1.372 \pm 0.275$ & 0.428662 \\
Zinc $(\mathrm{Zn}) \mathrm{mg} / \mathrm{L}$ & $0.211 \pm 0.050$ & $0.203 \pm 0.043$ & 0.397116 \\
\hline
\end{tabular}

Table 5: Serum trace elements level $($ Mean $\pm \mathrm{SD})$ in sheep infected with C. tenuicollis compared to non-infected sheep

\begin{tabular}{lccc}
\hline Trace elements & Infected group $(\mathrm{n}=40)$ & Non-infected group $(\mathrm{n}=10)$ & P-value of T-test \\
\hline Copper $(\mathrm{Cu}) \mathrm{mg} / \mathrm{L}$ & $1.42 \pm 0.466$ & $0.90 \pm 0.171$ & $* 0.00044213$ \\
Iron $(\mathrm{Fe}) \mathrm{mg} / \mathrm{L}$ & $1.42 \pm 0.388$ & $1.26 \pm 0.490$ & 0.26597930 \\
Zinc $(\mathrm{Zn}) \mathrm{mg} / \mathrm{L}$ & $0.37 \pm 0.230$ & $0.70 \pm 0.108$ & $* 0.00014191$ \\
\hline
\end{tabular}




\section{Discussion}

\section{Protein profiles estimation}

C. tenuicollis infection in animals results in economical loses and decreasing the meat quality (13). In addition, it might cause alteration in the level of different blood parameters (15). The effect of $C$. tenuicollis on biochemical and hematological parameters is not well studies in animals, so this study tries to trace the changes in some blood parameters due to the parasitic infection.

The findings of the current study unveiled that biochemical parameters (serum total protein and globulin) were increased significantly in infected sheep compared with control group. Similar results reported in Duhok by Al-Bayati et al (20) who investigated that plasma total protein was increased in sheep infected with $C$. tenuicollis. The theories about alteration of protein level in blood plasma are controversial. In some studies, it's shown that during parasitic infection, larval stages of parasites absorb proteins from the host for their lives (21-24). On the other hand, it's found that the level of total blood protein increased due to inflammatory responses of the host (25). The outer layer of metacestodes, teguments, of some parasitic cestodes such as Taenia crassiceps (21) and Echinococcus granulosus (22) is composed of large amount of structural proteins and enzymes. It's revealed previously that the cyst absorbs structural protein from body fluid. This finding was also confirmed by Shepherd and McManus (23) using Immunoprecipitation and by Shapiro et al (24) using immunoblot analysis. Several host proteins were found in adult and cysts of the worm through these laboratory tests. The host inflammatory response was discovered to increase in acute and chronic parasitic infection which causes an increase in serum globulin (25). In other parasitic infection, a study conducted by Esmaeilnejad et al (26) on Babesia ovis in sheep revealed comparable values with our results concerning total serum protein, albumin and globulin. The present findings are inconsistent with those found by Bamorovat et al (16) who found that no significant changes were seen in serum levels of total protein in sheep infected with $C$. tenuicollis. Also, its disagreement with that found by Radfar et al (27) who recorded that total serum protein was decreased significantly in infected goats compared with control group.

It seemed from the results of this study that serum albumin had significantly decreased in sheep infected with C. tenuicollis compared with non-infected ones. The migration of $C$. tenucollis cause traumatic hepatitis (28). The same effect is also shown in liver fluke infection due to destruction of the liver cells during larvae migration. When the disease becomes chronic, it leads to reduce the amount of blood albumin due to decrease the ability of liver to produce albumin (29). The obtained results were accordant with those recorded by Esmaeilnejad et al (26) signaled that serum albumin had significantly decreased in sheep infected with B. ovis compared with healthy one.

\section{Trace elements estimation}

In this study, it was found that the mean serum levels of $\mathrm{Cu}$ were increased, while the mean serum $\mathrm{Zn}$ level was decreased in sheep infected with $C$. tenuicollis when compared with healthy ones. It appears from the findings of the study that the serum Fe value was slightly higher in infected cases than non-infected ones, but it was within normal range. As far as we know, no previous study had been published to show the correlation between trace elements and the effect of $C$. tenuicollis infection. Comparing our results with other parasitic infections, our finding is in agreement with that found by (30) they found that sheep infected with cystic echinococcosis had a decreased of $\mathrm{Zn}$ levels and an increased of $\mathrm{Cu}$ levels. The results could be explained that growing parasite lead to increase consumption of $\mathrm{Zn}$ and secretion of $\mathrm{Cu}$ into the circulation (7). Serum can store $90 \%$ of $\mathrm{Cu}$ in the bound form of ceruloplasmin, while it's unable to store $\mathrm{Zn}$ and the level of $\mathrm{Zn}$ could be decline easily. The raising level of $\mathrm{Cu}$ is in connection with the level of ceruloplasmin such as observed in acute phase reactant (31). Also, similar results reported by Dedes et al (6) who was showed that equine piroplasmosis result in decreased plasma $\mathrm{Zn}$ level and increased $\mathrm{Cu}$ level. Furthermore, our recorded corroborate the opinion of (32) who reported that Hepatozoon canis caused an increased in serum $\mathrm{Cu}$ level and a decreased in $\mathrm{Zn}$ level. Contrary to our results, Seyrek et al (32) mentioned that serum Fe decreased in dog infected with $H$. canis. Many factors have been explained to reduce the level of $\mathrm{Zn}$ in the serum of animal including indirect effect of the host-parasite relationship or increased $\mathrm{Zn}$ demand by the parasite itself (33), and hormonal changes (34).

\section{Conclusion}

In conclusion, the serum total protein, globulin, and $\mathrm{Cu}$ values were increased in sheep infected with $T$. hydatigena cysts. While the serum albumin, and $\mathrm{Zn}$ values were decreased. In the light of this study, it is recommended to conduct further study to compare the effect of parasite on trace elements concentration in serum, cystic fluid and host tissues in other ruminants.

\section{Acknowledgements}

The authors thank all veterinary staff at Modern Sulaymaniyah Slaughterhouse for their assistance and facility during animal handling and sample collection. We also would like to thank the staff of Baxshin Private Hospital and Kurdistan Institution for Strategic Studies and Scientific Research / Sulaymaniyah city for their 
appreciation and cooperation during specimen analysis. The findings described in this paper are a part of $\mathrm{PhD}$ thesis of the corresponding author.

\section{References}

1. Scala A, Pipia AP, Dore F, Sanna G, Tamponi C, Marrosu L, Bandino E, Carmona C, Boufana B, Varcasia A. Epidemiological updates and economic losses due to Taenia hydatigena in sheep from Sardinia, Italy. Parasitol Res. 2015;114(8):3137-3143. DOI: 10.1007/s00436015-4532-x.

2. Blazek K, Schramlova J, Hulinsk D. Pathology of the migration phase of Taenia hydatigena larvae. Folia Parasitol. 1985;32:127-137. Pubmed/4007699.

3. Christodoulopoulos G, Theodoropoulos G, Petrakos G. Epidemiological survey of cestode-larva disease in Greek sheep flocks. Vet Parasitol. 2008;153(3):368-373. DOI: 10.1016/j.vetpar.2008.02.002.

4. Scala A, Urrai G, Varcasia A, Nicolussi P, Mulas M, Goddi L, Pipia AP, Sanna G, Genchi M, Bandino E. Acute visceral cysticercosis by Taenia hydatigena in lambs and treatment with praziquantel. J Helminthol. 2014;14:1-4. DOI: 10.1017/S0022149X14000601.

5. Abidi S, Nizami W, Khan P, Ahmed M, Irshadullah M. Biochemical characterization of Taenia hydatigena cysticerci from goats and pigs. J Helminthol. 1989;63(4):333-337. DOI: 10.1017/s0022149x00009238.

6. Dede S, Değer Y, Değer S, Tanrıtanır P. Plasma levels of zinc, copper, copper/zinc ratio, and activity of carbonic anhydrase in equine piroplasmosis. Biol Trace Elem Res. 2008;125(1):41-45. DOI: 10.1007/s12011-008-8136-5

7. Sakman G, Parsak CK, Koltaş İS, Seydaoğlu G, Sönmez H, Hanta I. Evaluating the trace elements in preoperative and postoperative duration of hydatid surgery. Saudi Med J. 2008;29(1):69-74. Pubmed/18176676.

8. Rivera MT, Souza APD, Araujo-Jorge TC, De Castro SL, Vanderpas J. Trace elements, innate immune response and parasites. Clin Chem Lab Med. 2003;41(8):1020-1025. DOI: 10.1515/cclm.2003.156.

9. Kassu A, Yabutani T, Mahmud ZH, Mohammad A, Nguyen N, Huong BTM, Hailemariam G, Diro E, Ayele B, Wondmikun Y, Motonaka J. Alterations in serum levels of trace elements in tuberculosis and HIV infections. Eur J Clin Nutr. 2006;60(5):580-586. DOI: $10.1038 /$ sj.ejcn. 1602352 .

10. Forlano MD, Teixeira KRS, Scofild A, Elisei C, Yotoko KSC, Fernandes KR, Linhares GFC, Ewing SA, Massard CL. Molecular characterization of Hepatozoon sp. from Brazilian dogs and its phylogenetic relationship with other Hepatozoon spp. Vet Parasitol. 2007;145(1):21-30. DOI: 10.1016/j.vetpar.2006.10.023.

11. Forlano M, Scofild A, Elisei C, Fernandes KR, Ewing SA, Massard CL. Diagnosis of Hepatozoon spp. in Amblyomma ovale and its experimental transmission to domestic dogs in Brazil. Vet Parasitol. 2005;134(1):1-7. DOI: 10.1016/j.vetpar.2005.05.066.

12. Klasing KC. Nutritional aspects of leukocytic cytokines. J Nutr. 1988;118(12):1436-1446. DOI: 10.1093/jn/118.12.1436.

13. Wondimu A, Albera D, Hailu Y. A study on the prevalence, distribution and economic importance of Cysticercus tenuicollis in visceral organs in small ruminants slaughtered at an abattoir in Ethiopia. J Vet Med Anim Health. 2011;3(5):67-74. http://citeseerx.ist.psu.edu/viewdoc/download?doi=10.1.1.828.6366\&r ep=rep1\&type=pdf.

14. Jenkins DJ, Urmin NAR, Williams TM, Mitchell TA, Lievaart JJ, Armua MT. Red foxes (Vulpes vulpes) and wild dogs (dingoes (Canis lupus dingo) and dingo/ domestic dog hybrids), as sylvatic hosts for Australian Taenia hydatigena and Taenia ovis. Int $\mathrm{J}$ Parasitol. 2014:3:75-80. DOI: 10.1016/j.ijppaw.2014.03.001.

15. Berezhko VK. Comparative immunochemical characteristics and serological activity of the antigens of Cysticercus tenuicollis and Taenia hydatigena. Parazitologiia. 1989;5:399-406. Pubmed/2482474.
16. Bamorovat M, Radfar MH, Derakhshanfar A, Molazadeh M, Zarandi MB. A comparative evaluation of hematological, biochemical and pathological changes among infected sheep with Cysticercus tenuicollis and non-infected control group. J Parasit Dis. 2014;38(4):339-403. DOI: 10.1007/s12639-013-0254-0.

17. Zajac AM, Conboy GA. Veterinary clinical parasitology. 8th ed. USA: John Wiley \& Sons; 2012. 5,186 p.

18. Eckersall PD. Proteins, proteomics, and the dysproteinemias. In: Kaneko JJ, Harvey JW, Bruss ML editors. Clinical biochemistry of domestic animals. 6th ed. California: Elsevier Academic Press; 2008. $117-155 \mathrm{p}$.

19. Tarhan D, Ülgen S, Alkan FA, Erdikmen DO, Yaramis CP, Or ME, Barutçu ÜB. Evaluation of tear and serum trace elements (copper, selenium, and cobalt) in sheep. Turkish $J$ Vet Anim Sci. 2016;40(1):34-39. DOI: 10.3906/vet-1501-98.

20. Al-Bayati SM, Azeez OH, Abdullah AM. Biochemical and histological study of Cysticercus tenuicollis of sheep in Duhok province. Basrah J Vet Res. 2012;11(1):52-57. DOI: 10.33762/bvetr.2012.54753.

21. Naquira C, Paulin J, Agosin M. Taenia crassiceps: Protein synthesis in larvae. Exp Parasitol. 1977;41(2):359-369. DOI: 10.1016/00144894(77)90108-4.

22. Agosin M, Repetto Y. Studies on the metabolism of Echinococcus granulosus: IX. Protein synthesis in scolices. Exp Parasitol. 1976;21(2):195-208. DOI: 10.1016/0014-4894(67)90081-1.

23. Shepherd JC, McManus DP. Specific and cross-reactive antigens of Echinococcus granulosus hydatid cyst fluid. Mol Biochem Parasitol. 1987;25(2):143-154. DOI: 10.1016/0166-6851(87)90003-x.

24. Shapiro SZ, Bahr GM, Hira PR. Analysis of host components in hydatid cyst fluid and immunoblot diagnosis of human Echinococcus granulosus infection. Ann Trop Med Parasitol. 1992;86(5):503-509. DOI: 10.1080/00034983.1992.11812699.

25. Gammopathies MVP. Understanding and interpreting serum protein electrophoresis. Am Fam Physician. 2005;71:105-112. Pubmed/15663032.

26. Esmaeilnejad B, Tavassoli M, Asri-Rezaei S, Dalir-Naghadeh B, Pourseyed SH. Evaluation of serum total protein concentration and protein fractions in sheep naturally infected with Babesia ovis. Comp Clin Pathol. 2014:23(1):151-155. DOI:10.1007/s00580-012-1587-2.

27. Radfar MH, Zarandi MB, Bamorovat M, Kheirandish R, Sharifi I. Hematological, biochemical and pathological findings in goats naturally infection with Cysticercus tenuicollis. J Parasit Dis. 2014;38(1):68-72. DOI: 10.1007/s12639-012-0188-y.

28. Soulsby EJL. Helminths, arthropods and protozoa of domesticated animals. 7th ed. London: Baillier and Tindall; 1986. 113-115 p.

29. Lee JS. Albumin for end-stage liver disease. Korean J Int Med. 2012;27(1):13. DOI: 10.3904/kjim.2012.27.1.13.

30. Ozen N, Celik C, Ozkan K, Malazgirt Z, Isimer A, Sayal A. Trace elements in hydatid disease. J Trace Elem Electrol Health Dis. 1992;6(2):67-70. Pubmed/1422183.

31. Zarebavani M, Dargahi D, Einollahi N, Dashti N, Mohebali M, Rezaeian M. Serum levels of zinc, copper, vitamin B12, folate and immunoglobulins in individuals with giardiasis. Iran J Pub Health. 2012;41(12):47. PMCID: PMC3640781

32. Seyrek K, Karagenç T, Paşa S, Kıral F, Atasoy A. Serum zinc, iron and copper concentrations in dogs infected with Hepatozoon canis. Acta Vet Brno. 2009;78(3):471-475. DOI: 10.2754/avb200978030471.

33. Lindskog S. Structure and mechanism of carbonic anhydrase. Pharmacol Ther. 1997;74(1):1-20. DOI: 10.1016/s01637258(96)00198-2.

34. Kocyigit A, Erel O, Gurel MS, Avci S, Aktepe N. Alterations of serum selenium, zinc, copper, and iron concentrations and some related antioxidant enzyme activities in patients with cutaneous leishmaniasis. Biol Trace Elem Res.1998;65(3):271-281. DOI: 10.1007/BF02789102. 